\title{
Effect of acute and chronic hypoxia on the swimming performance, metabolic capacity and cardiac function of Atlantic cod (Gadus morhua)
}

\author{
L. H. Petersen* and A. K. Gamperl ${ }^{\dagger}$ \\ Ocean Sciences Centre, Memorial University of Newfoundland, St John's, NL, Canada, A1C 5S7 \\ *Present address: Institute of Applied Science, University of North Texas, 1125 Union Circle, PO Box 310559, Denton, TX 76203, USA \\ ${ }^{\dagger}$ Author for correspondence (kgamperl@mun.ca)
}

Accepted 23 November 2009

\begin{abstract}
SUMMARY
Low water oxygen content (hypoxia) is a common feature of many freshwater and marine environments. However, we have a poor understanding of the degree to which diminished cardiac function contributes to the reduction in fish swimming performance concomitant with acute exposure to hypoxia, or how fish cardiorespiratory physiology is altered by, or adapts to, chronic hypoxia. Thus, we acclimated adult Atlantic cod (Gadus morhua) to either $\sim 8-9 \mathrm{kPa} \mathrm{O}\left(40-45 \%\right.$ air saturation) or $\sim 21 \mathrm{kPaO} \mathrm{O}_{2}(100 \%$ air saturation; normoxia) for $6-12$ weeks at $10^{\circ} \mathrm{C}$, and subsequently measured metabolic variables [routine oxygen consumption $\left(\dot{M}_{\mathrm{O}_{2}}\right)$, maximum $\dot{M}_{\mathrm{O}_{2}}$, metabolic scope] and cardiac function (cardiac output, $\dot{Q}$; heart rate, $f_{\mathrm{H}}$; and stroke volume, $V_{\mathrm{S}}$ ) in these fish during critical swimming speed $\left(U_{\text {crit }}\right)$ tests performed at both levels of water oxygenation. Although surgery (flow probe implantation) reduced the $U_{\text {crit }}$ of normoxia-acclimated cod by $14 \%$ (from 1.74 to $1.50 B \mathrm{~L} \mathrm{~s}^{-1}$ ) under normoxic conditions, exposure to acute hypoxia lowered the $U_{\text {crit }}$ of both groups (surgery and non-surgery) by $\sim 30 \%$ (to 1.23 and $1.02 B L s^{-1}$, respectively). This reduction in swimming performance was associated with large decreases in maximum $\dot{M}_{2}$ and metabolic scope ( $\geq 50 \%$ ), and maximum $f_{\mathrm{H}}$ and $\dot{Q}$ (by 16 and 22\%), but not $V_{\mathrm{S}}$. Long-term acclimation to hypoxia resulted in a significant elevation in normoxic metabolic rate as compared with normoxia-acclimated fish (by $27 \%$ ), but did not influence normoxic or hypoxic values for $U_{\text {crit, }}$ maximum $\dot{\mathrm{M}}_{2}$ or metabolic scope. This was surprising given that resting and maximum values for $\dot{Q}$ were significantly lower in hypoxia-acclimated cod at both levels of oxygenation, because of lower values for $V_{s}$. However, hypoxia-acclimated cod were able to consume more oxygen for a given cardiac output. These results provide important insights into how fish cardiorespiratory physiology is impacted by short-term and prolonged exposure to hypoxia, and further highlight the tremendous capacity of the fish cardiorespiratory system to deal with environmental challenges.
\end{abstract}

Key words: hypoxia, heart, exercise, oxygen consumption, cardiac output, critical swimming speed.

\section{INTRODUCTION}

Hypoxia is a frequently occurring environmental phenomenon in many freshwater and coastal systems, and can be caused by either anthropogenic input, or naturally occurring biological and physical factors (Rosenberg et al., 1991; Pihl et al., 1992; Hoback and Barnhart, 1996; Wu, 1999). Recent studies show that hypoxia in marine waters is not restricted to localized areas, but is more extensive and longer-lasting (weeks to months) than previously thought (Diaz and Rosenberg, 1995; Wu, 1999; Weeks et al., 2002; Bell and Eggleston, 2005; Gilbert et al., 2005). This can create inhospitable habitats for fish and sedentary animals (Wu, 2002), and severe oxygen depletion of coastal waters has significant negative consequences for economically important fisheries, ecosystems and biodiversity (UN Global Environment Outlook Year Book, 2003). These problems become even more serious if large areas are affected by hypoxia for an extended time, as fish may not be able to leave these areas; avoidance being the predominant reaction to hypoxia (Pihl et al., 1991; Claireaux et al., 1995).

Locomotor performance is determined by the interaction of many organ systems, and is considered to be an integrated measure of an animal's physiological capacity in a particular environment (Nelson, 1989). Thus, measuring the locomotor performance of fishes could provide valuable information on their physiological response to hypoxia. Furthermore, cardiorespiratory adjustments are a prerequisite for vital functions (e.g. locomotion, digestion) and for appropriate responses to environmental changes (Farrell, 2002;
Claireaux et al., 2005; Gollock et al., 2006; Clark and Seymour, 2006; Steinhausen et al., 2008), and an understanding of how chronic hypoxia affects both swimming performance and cardiovascular function could reveal important information about whether fish will survive, and how well they adapt to, hypoxic environments. At present, studies on the effects of chronic (weeks of) hypoxia have been conducted on a limited number of teleost species, and focused on a range of aspects such as food intake (Chabot and Dutil, 1999; Pichavant et al., 2000; Pichavant et al., 2001; Zhou et al., 2001), reproduction (Wu et al., 2003), oxygen carrying capacity (Greaney et al., 1980; Taylor and Miller, 2001; Pichavant et al., 2003), cardiomyocyte physiology (Lennard and Huddart, 1992; Paajanen and Vornanen, 2003) and circulating catecholamine levels (Butler et al., 1979; Montpetit and Perry, 1998). However, to our knowledge only two studies (Kutty, 1968; Bushnell et al., 1984) have investigated how chronic hypoxia affects fish swimming performance and metabolism, and only one study (Burleson et al., 2002) has examined the effect of chronic hypoxia on fish in vivo cardiovascular function. Furthermore, this lack of information is surprising given that: (1) acute exposure to reduced oxygen levels decreases metabolic scope (Claireaux et al., 2000; Evans, 2007) and swimming performance (Dahlberg et al., 1968; Kutty, 1968; Bushnell et al., 1984; Dutil et al., 2007); and (2) hypoxia induces bradycardia in many species, and stroke volume must increase if the fish is to maintain or elevate cardiac output (Saunders, 1963; Wood and Shelton, 1980; Fritsche and Nilsson, 1989; Gamperl et 
al., 1994; Sandblom and Axelsson, 2005; Sandblom and Axelsson, 2006).

The Atlantic cod (Gadus morhua L.) is a demersal North Atlantic species of significant economic and cultural importance that has experienced dramatic population declines over the past several decades (Myers et al., 1996; Svedäng and Bardon, 2003; Hutchings and Reynolds, 2004). Further, this species has traditionally inhabited areas, such as the Baltic Sea (Gerlach, 1988) and the Gulf of St Lawrence (GSL) (D'Amours, 1993; Kiceniuk and Colbourne, 1997; Gilbert et al., 2005), where they are now likely to encounter environmental oxygen levels that may strongly affect their distribution, growth and reproduction, at least during part of their life history. For example, GSL cod are sensitive to hypoxia (D'Amours, 1993), completely avoid regions of water oxygen partial pressures $\left(P_{\mathrm{W}_{2}}\right)$ below a threshold of $\sim 6.6 \mathrm{kPa}$ (Kiceniuk and Colbourne, 1997), and there are thus areas in the GSL that are below the threshold for survival (Plante et al., 1998; Gilbert et al., 2005).

Given the expanding threat of hypoxia for marine organisms including cod (Breitburg, 2002; Neuenfeldt, 2002; Wu et al., 2002; Gilbert et al., 2005), and our incomplete understanding of fish physiology when exposed to low oxygen conditions, the main goal of the present study was to determine whether Atlantic cod are able to adapt to chronic hypoxia. Thus, we acclimated adult Newfoundland cod to water oxygen levels $\left(P_{\mathrm{w}_{2}}\right)$ of $8-9 \mathrm{kPa}$ (hypoxia) and $21 \mathrm{kPa}$ (normoxia) for 6-12 weeks, fitted them with Transonic ${ }^{\circledR}$ flow probes around their ventral aorta, and measured cardiac function and oxygen consumption during critical swimming speed $\left(U_{\text {crit }}\right)$ tests conducted at both water oxygen levels.

\section{MATERIALS AND METHODS}

These studies were conducted in accordance with the guidelines of the Canadian Council on Animal Care, and approved by the Institutional Animal Care Committee of Memorial University of Newfoundland (Protocol \# 05-03-KG).

\section{Experimental animals}

Experiments were performed on adult $(0.62 \pm 0.03 \mathrm{~kg}$; range $=0.43-0.78 \mathrm{~kg} ; N=31$ ) Atlantic cod at the Ocean Sciences Centre (OSC; Memorial University, St John's, Newfoundland, Canada). Cod were obtained from stocks reared at the OSC's Aquaculture Research and Development Facility (ARDF), and subsequently held in sea cages at Hermitage Bay (Newfoundland, Canada) for approximately 18 months before being transported back to the OSC. At the OSC, the cod were originally held in a 12,0001 tank supplied with aerated seawater at $10^{\circ} \mathrm{C}$ for at least 2 months prior to being moved to acclimation tanks. During this period, the fish were fed a commercial cod diet (EWOS, Canada) three times a week, and photoperiod was maintained at $12 \mathrm{~h}: 12 \mathrm{~h}$ light:dark.

\section{Experimental conditions \\ Acclimation to normoxia}

Prior to experiments, 20 fish from the holding tank were acclimated at a $P \mathrm{~W}_{\mathrm{O}_{2}}$ of $21 \mathrm{kPa}$ for $6-12$ weeks at $10 \pm 0.1^{\circ} \mathrm{C}$ in two $\sim 13001$ tanks, each supplied with aerated seawater from a header tank at a flow-rate of $\sim 6-81 \mathrm{~min}^{-1}$. The header tank was fitted with two submersible heaters (Process Technology, OH, USA; model NA15E-2) and connected to a separate heater/chiller (custom built by Technical Services, Memorial University of Newfoundland). Furthermore, a wooden lid was placed on the tank to reduce stress from external stimuli (presence of people, noise, etc.) and to reduce fluctuations in water temperature. The normoxia acclimation tank was fully aerated to ensure normoxic conditions $(>20 \mathrm{kPa})$, and fish were fed three times a week with commercial cod pellets at a ration equal to that consumed by the hypoxic group.

\section{Acclimation to hypoxia}

The hypoxia acclimation tank was supplied with ambient seawater from its own header tank, and fitted with a wooden lid to reduce noise and fluctuations in water temperature, and to reduce the exchange of oxygen with the atmosphere. Temperature in the hypoxic tank was controlled by a small submersible rod-type heater (Process Technology; model DRAE15-1) fitted on the lid and by circulating water in the tank through a custom built heater/chiller (Technical Services, Memorial University of Newfoundland). These two systems were sufficient to maintain water temperature at $10 \pm 0.1^{\circ} \mathrm{C}$.

Twenty fish were transferred from the holding tank to the hypoxia acclimation tank and held under normoxic conditions $(>20 \mathrm{kPa})$ for 1 week before the oxygen level was reduced. A hypoxia level of $\sim 8 \mathrm{kPa}$ ( $\sim 40 \%$ air saturation) was achieved over the time course of 1 week by: (1) slowly reducing the flow rate to the tank to $1-21 \mathrm{~min}^{-1}$ (i.e. fish metabolism partially reduced the water $\mathrm{O}_{2}$ content); and (2) using a custom designed solenoid valve system (Electronics Workshop, Memorial University of Newfoundland). This system continuously monitored the oxygen level in the tank by pumping water through an external circuit of tubing (Tygon Food, ser. 6-419, Cole Parmer, Montreal, QC, Canada) that contained a galvanic oxygen electrode (model CellOx 325, WTW, Weilheim, Germany) housed in a D201 flow cell (WTW). Further, the oxygen probe was connected to an oxygen meter (model Oxi 340, WTW), which was subsequently connected to two solenoid valves; one that bubbled pure $\mathrm{N}_{2}$ into the tank when $\mathrm{O}_{2}$ reached an upper limit of $9 \mathrm{kPa}$, and the other bubbled air into the tank when oxygen levels reached $7 \mathrm{kPa}$. This design allowed the oxygen level in the hypoxic tank to be kept within a narrow $\mathrm{O}_{2}$ range $( \pm 1 \mathrm{kPa})$, and together with the reduced water flow, proved to be highly efficient in maintaining appropriate $\mathrm{O}_{2}$ levels; average $\mathrm{O}_{2}$ level $8.6 \pm 0.2 \mathrm{kPa}$ over the $6-12$ week acclimation period.

Fish were fed three times a week with commercial cod pellets, and most fish were feeding from the first day of reaching $8-9 \mathrm{kPa}$; average food consumption over the period of acclimation $1.4 \%$ body mass day ${ }^{-1}$. To avoid the build up of carbon dioxide and nitrogen that may have affected the hypoxic fish, we tested water quality (total nitrogen, un-ionized ammonia, $P_{\mathrm{CO}_{2}}$ and $\mathrm{pH}$ ) in the hypoxic tank once a week throughout acclimation.

\section{Surgical procedures}

With the exception of the 'non-surgery' group, the fish were netted and anaesthetized in seawater containing tricaine methane sulphonate (MS-222; $0.1 \mathrm{gl}^{-1}$ ) until ventilatory movements ceased. Then the fish were weighed and measured before being transferred to an operating table where chilled $\left(4^{\circ} \mathrm{C}\right)$ oxygenated seawater, containing a lower dose of MS-222 $\left(0.05 \mathrm{gl}^{-1}\right)$, was continuously pumped over the fish's gills.

To allow for the direct measurement of cardiac function (cardiac output, $\dot{Q}$; heart rate $f_{\mathrm{H}}$; and stroke volume, $V_{\mathrm{S}}$ ), a $2 \mathrm{~S}$ or $2.5 \mathrm{~S}$ Transonic ${ }^{\circledR}$ flow probe was fitted around the ventral aorta of each cod as previously described by Gollock et al. (Gollock et al., 2006). After the flow probe had been carefully placed around the vessel, it was connected to a flow meter (Transonic Systems Inc., Ithaca, NY, USA; Model TS-420) to test for correct placement of the probe, and the flow probe lead was secured to the cod's skin at three locations using silk suture (3-0, American Cyanamid Company, Pearl River, NY, USA): one location close to the incision, a second ventral to the pectoral fin, and a third close to the dorsal fin. 
Once surgery had been completed, the fish were transferred to the swim-tunnel, and all fish commenced ventilation within $<2 \mathrm{~min}$. The water velocity in the swim-tunnel was set at 0.25 body lengths per second $\left(B L \mathrm{~s}^{-1}\right.$; a velocity at which the fish did not swim actively, but had no trouble orienting themselves), and all fish were allowed at least $18 \mathrm{~h}$ of recovery in normoxic water prior to the first swim trial.

\section{Critical swimming speed tests}

Critical swimming speed $\left(U_{\text {crit }}\right)$ tests were performed in a 811 Blazka-type swim-tunnel respirometer (University of Waterloo, Biotelemetry Institute, Waterloo, ON, USA) with an internal diameter of $25 \mathrm{~cm}$ and a $90 \mathrm{~cm}$ long working section. The front of the respirometer was fitted with a plastic grid, which created uniform water flow in the swimming section of the respirometer (Taylor and McPhail, 1985), and the rear of the tunnel was fitted with a stainless steel grid connected to an external electrical circuit. This stainless steel grid could be electrified with a small current $(<5 \mathrm{~V}, \sim 0.2 \mathrm{~A})$ to discourage the fish from resting on the grid during swimming trials. Furthermore, the tunnel was covered with black plastic to provide the fish with a dark refuge, and to minimize stress from external stimuli (i.e. investigator's presence).

Water $(21$ or $8-9 \mathrm{kPa})$ was supplied to the swim-tunnel from a temperature-controlled 2701 water reservoir that was maintained at $10 \pm 0.1^{\circ} \mathrm{C}$ using a heater/chiller (Memorial University of Newfoundland, Technical Services). The $\mathrm{O}_{2}$ content of the water was controlled by bubbling pure $\mathrm{N}_{2}$ into the reservoir at rates predetermined to achieve the desired $\mathrm{O}_{2}$ level.

\section{Experimental protocol}

Resting and active oxygen consumption and cardiac function, and swimming performance, of individual fish were initially measured under normoxic conditions using a critical swimming speed test (Brett, 1964). After measuring cardiac function and oxygen consumption (see below) at the baseline speed of $0.25 B L \mathrm{~s}^{-1}$, swimming speed was increased in $0.125 B L \mathrm{~s}^{-1}$ increments every 20 min until the fish were exhausted; exhaustion was determined as the inability of the fish to move away from the electric grid after three successive mild $(5 \mathrm{~V})$ shocks. Thereafter, water velocity was returned to $0.25 B L \mathrm{~s}^{-1}$ and the fish left overnight to recover. During the morning of the second day, the oxygen level in the tunnel was reduced over a period of $3 \mathrm{~h}$ by bubbling pure $\mathrm{N}_{2}$ into the reservoir to reduce the oxygen level in the tunnel to $16 \mathrm{kPa}$ in the first hour, $12 \mathrm{kPa}$ in the second hour, and $8-9 \mathrm{kPa}$ by the end of the third hour. The oxygen level in the swim-tunnel was then maintained at $8-9 \mathrm{kPa}$ for $1 \mathrm{~h}$ before the hypoxic $U_{\text {crit }}$ trial was performed. The hypoxic $U_{\text {crit }}$ trial was identical to that performed during normoxia, and fish swum under hypoxic conditions were also allowed to recover under normoxic conditions; water $P_{\mathrm{W}_{2}}$ increased from $8-9 \mathrm{kPa}$ to $\sim 19 \mathrm{kPa}$ during the first $20 \mathrm{~min}$ of recovery. Fish swum under hypoxic conditions $\left(\mathrm{P}_{\mathrm{W}_{2}} 8-9 \mathrm{kPa}\right)$ were not recovered at this oxygen level because preliminary experiments on normoxia-acclimated fish showed that some individuals were having trouble righting themselves or swimming constantly even more than $2 \mathrm{~h}$ postexercise. This is also the main reason that the fish were swum in the same order; normoxia, then hypoxia.

For both normoxic and hypoxic swim trials, $U_{\text {crit }}$ was calculated as:

$$
U_{\text {crit }}=\mathbf{v}+\left(\left(\frac{t_{\mathrm{f}}}{t_{\mathrm{i}}}\right) \times \mathbf{v}_{\mathrm{i}}\right),
$$

where $\mathbf{v}$ is the highest velocity at which the fish swam for the entire time increment $\left(B L \mathrm{~s}^{-1}\right) ; \mathbf{v}_{\mathrm{i}}$ is velocity increment $\left(B L \mathrm{~s}^{-1}\right) ; t_{\mathrm{f}}$ is time elapsed from the last change in current velocity to fatigue (min); and $t_{\mathrm{i}}$ is time increment, the time between step increases in velocity (20 min).

Measurements of cardiac function and metabolism

Cardiac output $(\dot{Q})$ was continuously measured during the $U_{\text {crit }}$ trial and for $\sim 2 \mathrm{~h}$ after the fish became exhausted [i.e. measurements were taken immediately after the fish stopped swimming ( $0 \mathrm{~min})$, and at $25 \mathrm{~min}, 50 \mathrm{~min}, 75 \mathrm{~min}, 100 \mathrm{~min}$ and $125 \mathrm{~min}$ of recovery]. $\dot{Q}$ was measured by connecting the flow meter to a MP100A-CE data acquisition system and a laptop running AcqKnowledge software (BIOPAC Systems Inc., Santa Barbara, CA, USA). Data were recorded at a frequency of $20 \mathrm{~Hz}$, and values of cardiac output were obtained during the last $5 \mathrm{~min}$ at each swimming speed and during the first $5 \mathrm{~min}$ of each $25 \mathrm{~min}$ period during recovery. Cardiac output $\left(\dot{Q}\right.$, in $\left.\mathrm{ml} \mathrm{min}^{-1} \mathrm{~kg}^{-1}\right)$ was calculated by dividing the raw data $\left(\mathrm{ml} \mathrm{min}^{-1}\right)$ by the mass of the fish $(\mathrm{kg})$. Heart rate $\left(f_{\mathrm{H}}\right.$; beats $\left.\mathrm{min}^{-1}\right)$ was calculated by measuring the time required for 20 systolic peaks, and multiplying this value by 60 divided by the measurement period (s). Stroke volume $\left(V_{\mathrm{S}} ; \mathrm{ml} \mathrm{kg}^{-1}\right)$ was calculated as $\dot{Q} / f_{\mathrm{H}}$. Maximum values of $\dot{Q}, V_{\mathrm{S}}$ and $f_{\mathrm{H}}$ were measured as the highest value that each individual fish achieved. Finally, the absolute scope for cardiac variables $\left(\dot{Q}, V_{\mathrm{S}}\right.$ and $\left.f_{\mathrm{H}}\right)$ was calculated by subtracting routine (resting) values from maximum values.

Water temperature and oxygen concentration $\left(\mathrm{mg} \mathrm{O}_{2} \mathrm{l}^{-1}\right)$ in the swim tunnel were continuously measured via an external circuit containing an oxygen probe housed in a D201 flow through cell (see description for the hypoxia acclimation tank). Oxygen consumption $\left(\dot{M}_{\mathrm{O}_{2}}\right)$ of the cod was measured over $10 \mathrm{~min}$ intervals at rest, at each swimming speed, and at 0, 25, 50, 75, 100 and $125 \mathrm{~min}$ of recovery by stopping the flow of water into the swim-tunnel, recording the drop in water-oxygen concentration in the swimtunnel, and using the following equation (Cech, 1990):

$$
\dot{M}_{\mathrm{O}_{2}}=\frac{\left(\left(C_{\mathrm{i}}-C_{\mathrm{f}}\right) \times V_{\mathrm{c}}\right) \times 60}{M \times t},
$$

where $C_{\mathrm{i}}$ is water oxygen concentration $\left(\mathrm{mg} \mathrm{O}_{2} \mathrm{I}^{-1}\right)$ at the start of $\dot{M}_{\mathrm{O}_{2}}$ measurement; $C_{\mathrm{f}}$ is oxygen concentration $\left(\mathrm{mg} \mathrm{O}_{2} \mathrm{l}^{-1}\right)$ at the end of $\dot{M}_{\mathrm{O}_{2}}$ measurement; $V_{\mathrm{c}}$ is volume of the respirometer and external circuit (811); $M$ is fish mass $(\mathrm{kg})$; and $t$ is time required to make $\dot{M}_{\mathrm{O}_{2}}$ measurement $(10 \mathrm{~min})$. Note that water oxygen concentration only dropped by $\sim 0.1-0.3 \mathrm{mg} \mathrm{l}^{-1}$ over the measurement period.

Standard oxygen consumption was obtained from a semi-log plot of swimming speed $\left(B L \mathrm{~s}^{-1}\right)$ vs $\log \dot{M}_{\mathrm{O}_{2}}$, and using the derived linear regression to extrapolate back to $0 B L \mathrm{~s}^{-1}$. Maximum oxygen consumption $\left(\dot{M}_{\mathrm{O}_{2} \max }\right)$ was measured as the highest oxygen consumption that each individual fish achieved, and absolute metabolic scope was then calculated by subtracting routine (that of fish resting quietly in the tunnel) $\dot{M}_{\mathrm{O}_{2}}$ from $\dot{M}_{\mathrm{O}_{2} \max }$. Finally, each fish's total excess post-exercise oxygen consumption (EPOC; in $\mathrm{mg} \mathrm{O}_{2} \mathrm{~kg}^{-1}$; a measure of the non-aerobic cost of exercise) was obtained by integrating the area underneath the $\dot{M}_{\mathrm{O}_{2}}$-time curve until $\dot{M}_{\mathrm{O} 2}$ returned to routine values (see Lee et al., 2003).

The routine metabolic rate of fishes, including cod, scales allometrically with body mass with a slope of $\sim 0.8-0.85$ (Saunders, 1963; Post and Lee, 1996; Killen et al., 2007). However, isometrically scaled metabolic rate data (i.e. $\mathrm{mg} \mathrm{O}_{2} \mathrm{~h}^{-1} \mathrm{~kg}^{-1}$ ) are reported, because to our knowledge no metabolic scaling exponents have been reported for fish cardiovascular function, and we wanted to report all the variables using common units. Furthermore, the 
Table 1. Physical characteristics of the Atlantic cod used in the various experiments

\begin{tabular}{lccc}
\hline & \multicolumn{3}{c}{ Treatment } \\
\cline { 2 - 4 } & No surgery & Normoxia-acclimated & Hypoxia-acclimated \\
\hline Mass $(\mathrm{kg})$ & $0.55 \pm 0.03^{*}$ & $0.68 \pm 0.03$ & $0.57 \pm 0.04$ \\
Length $(\mathrm{cm})$ & $39.7 \pm 0.8$ & $41.9 \pm 0.9$ & $40.4 \pm 0.8$ \\
Condition factor $(\mathrm{K})$ & $0.90 \pm 0.04$ & $0.94 \pm 0.03$ & $0.86 \pm 0.03$ \\
\hline
\end{tabular}

*Significant difference between non-surgery and normoxia-acclimated groups. $N=9,10$ and 12 for the three groups. Values are means \pm s.e.m.

range of mass of the fish used was small, and thus the error in using isometric units would be minimal. However, we do provide allometrically scaled metabolic rates in the discussion when comparing our data with the literature.

Effect of surgery on swimming performance and metabolism We did not want to give the hypoxic fish an extended period of exposure to normoxic water prior to the initial $U_{\text {crit }}$ test. However, we were also cognisant of the fact that surgery and/or the postsurgical recovery period can potentially affect swimming and cardiovascular performance (e.g. Butler et al., 1989; Campbell et al., 2004) [also see figure 7 in Webber et al. (Webber et al., 1998)]. Thus, normoxic and hypoxic swim trials were also performed on nine $(0.55 \pm 0.03 \mathrm{~kg})$ normoxia-acclimated cod that did not undergo surgery or anaesthesia (non-surgery group). These fish were placed directly in the swim tunnel after being netted from their acclimation tank and allowed $\sim 18 \mathrm{~h}$ to recover.

\section{Statistical analyses}

A one-way ANOVA was used to examine whether fish mass, length and condition factor were affected by chronic acclimation to hypoxic conditions (Table 1). Two-way ANOVAs with repeated measures were used to determine at which swimming speeds or times during recovery $\dot{M}_{\mathrm{O}_{2}}$ and cardiovascular variables were different between: (1) surgery vs non-surgery groups (Fig. 1); and (2) normoxia- $v s$ hypoxia-acclimated cod (Fig. 2). This analysis was also used to determine at which values of water $\mathrm{O}_{2}$ saturation variables were different between normoxia- and hypoxia-acclimated cod during the step-down period (Fig. 3). Furthermore, Dunnett's post-hoc tests were performed to examine if/when variables became different from values at $100 \%$ air saturation (Fig. 3). Two-way ANOVAs with repeated measures, followed by paired (normoxic $v s$ hypoxic swim) or unpaired (normoxia- $v s$ hypoxia-acclimated or surgery $v s$ non-surgery) $t$-tests were used to identify differences in metabolic and cardiovascular variables (see Tables 2 and 3). Finally Pearson's correlation analysis was carried out to define the strength of the relationship between oxygen consumption and cardiac output during the normoxic and hypoxic swims and graded hypoxia
(Fig. 4). All data presented in figures, tables and the text are means \pm standard error (s.e.m.). Statistical analyses were carried out using SPSS (v.13.0; SPSS, Chicago, IL, USA) and a difference was considered significant when $P<0.05$.

\section{RESULTS}

Water quality in the hypoxic tank did not deteriorate during the $6-12$ weeks of acclimation to hypoxia. Mean values $(N=10-12)$ for total nitrogen, un-ionized ammonia, carbon dioxide and $\mathrm{pH}$ were $0.03 \pm 0.01$ p.p.m.: $0.0003 \pm 0.0$ p.p.m., $2.3 \pm 0.6$ p.p.m. and $7.8 \pm 0.1$, respectively. Further, although the mass of hypoxia-acclimated cod was $\sim 15 \%$ lower as compared with those held under normoxic conditions, neither this variable or condition factor were significantly different between the two groups (Table 1).

\section{Effects of anaesthesia and surgery}

Surgery resulted in a $14 \%$ decrease in the normoxic $U_{\text {crit }}$ value (from 1.74 to $1.50 \mathrm{BL} \mathrm{s}^{-1}$ ). However, the effect of surgery was similar when the fish were swum under hypoxia (17\% decrease), and as a result, the reduction in $U_{\text {crit }}$ between normoxic and hypoxic conditions was similar for both groups (non-surgery, 29\%; surgery, $32 \%$; Table 2). This pattern of change in swimming performance was not reflected by most metabolic variables: (1) cod fitted with flow probes had significantly lower routine and standard metabolic rates (by $\sim 25 \%$ ) when measured under normoxic conditions; (2) surgery had no significant effect on normoxic values of $\dot{M}_{\mathrm{O}_{2} \max }$ or metabolic scope; and (3) $\dot{M}_{\mathrm{O}_{2} \max }$ and metabolic scope decreased to a much greater extent in the surgery group compared with the non-surgery group when they were swum at $8-9 \mathrm{kPa}(57 \%$ vs $43 \%$ and $80 \%$ vs $55 \%$, respectively; Table 2, Fig. 1). Finally, EPOC was significantly $(P<0.05)$ lower in the surgery group when swum under normoxia and hypoxia (by $42 \%$ and $46 \%$, respectively; Table 2).

\section{Normoxic $U_{\text {crit }}$ test}

In normoxic water, routine $f_{\mathrm{H}}, V_{\mathrm{S}}, \dot{Q}$ and $\dot{M}_{\mathrm{O} 2}$ averaged $32.9 \pm 2.2$ beats $\min ^{-1}, 0.73 \pm 0.07 \mathrm{ml} \mathrm{kg}^{-1}, 23.1 \pm 1.8 \mathrm{ml} \mathrm{min}^{-1} \mathrm{~kg}^{-1}$ and $63.5 \pm 2.4 \mathrm{mg} \mathrm{O}_{2} \mathrm{~h}^{-1} \mathrm{~kg}^{-1}$, respectively for the 10 normoxia-acclimated

Table 2. The effect of surgery and anaesthesia on swimming performance and oxygen consumption of Atlantic cod measured under normoxia $\left(P \mathrm{~W}_{\mathrm{O}_{2}} \sim 20 \mathrm{kPa}\right)$ and hypoxia $\left(P \mathrm{~W}_{\mathrm{O}_{2}} \sim 8-9 \mathrm{kPa}\right)$

\begin{tabular}{|c|c|c|c|c|}
\hline & \multicolumn{2}{|c|}{ Non-surgery } & \multicolumn{2}{|c|}{ Surgery (normoxia-acclimated group) } \\
\hline & Normoxic swim & Hypoxic swim & Normoxic swim & Hypoxic swim \\
\hline SMR & $64.3 \pm 8.8^{\mathrm{a}, \star}$ & $53.6 \pm 7.4$ & $47.4 \pm 2.0$ & $55.3 \pm 4.1$ \\
\hline $\operatorname{Max} \dot{M}_{\mathrm{O}_{2}}$ & $234.6 \pm 21.2^{\mathrm{a}}$ & $133.1 \pm 8.8^{*}$ & $214.1 \pm 10.6^{a}$ & $92.7 \pm 3.4$ \\
\hline Scope & $152.1 \pm 20.7^{\mathrm{a}}$ & $67.8 \pm 8.0^{*}$ & $150.6 \pm 10.0^{\mathrm{a}}$ & $29.2 \pm 4.1$ \\
\hline EPOC & $73.1 \pm 11.9^{\mathrm{a}, \star}$ & $47.7 \pm 3.4^{\star}$ & $42.6 \pm 4.3$ & $28.0 \pm 7.7$ \\
\hline$U_{\text {crit }}$ & $1.74 \pm 0.06^{\star}$ & $1.23 \pm 0.05^{*}$ & $1.50 \pm 0.04^{\mathrm{a}}$ & $1.02 \pm 0.03$ \\
\hline
\end{tabular}

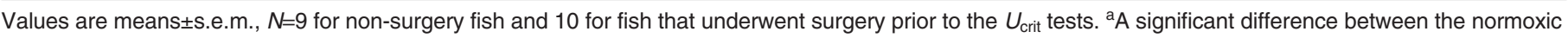
and hypoxic swim within each acclimation condition. *A significant difference between groups (non-surgery vs surgery) within a particular test condition. 

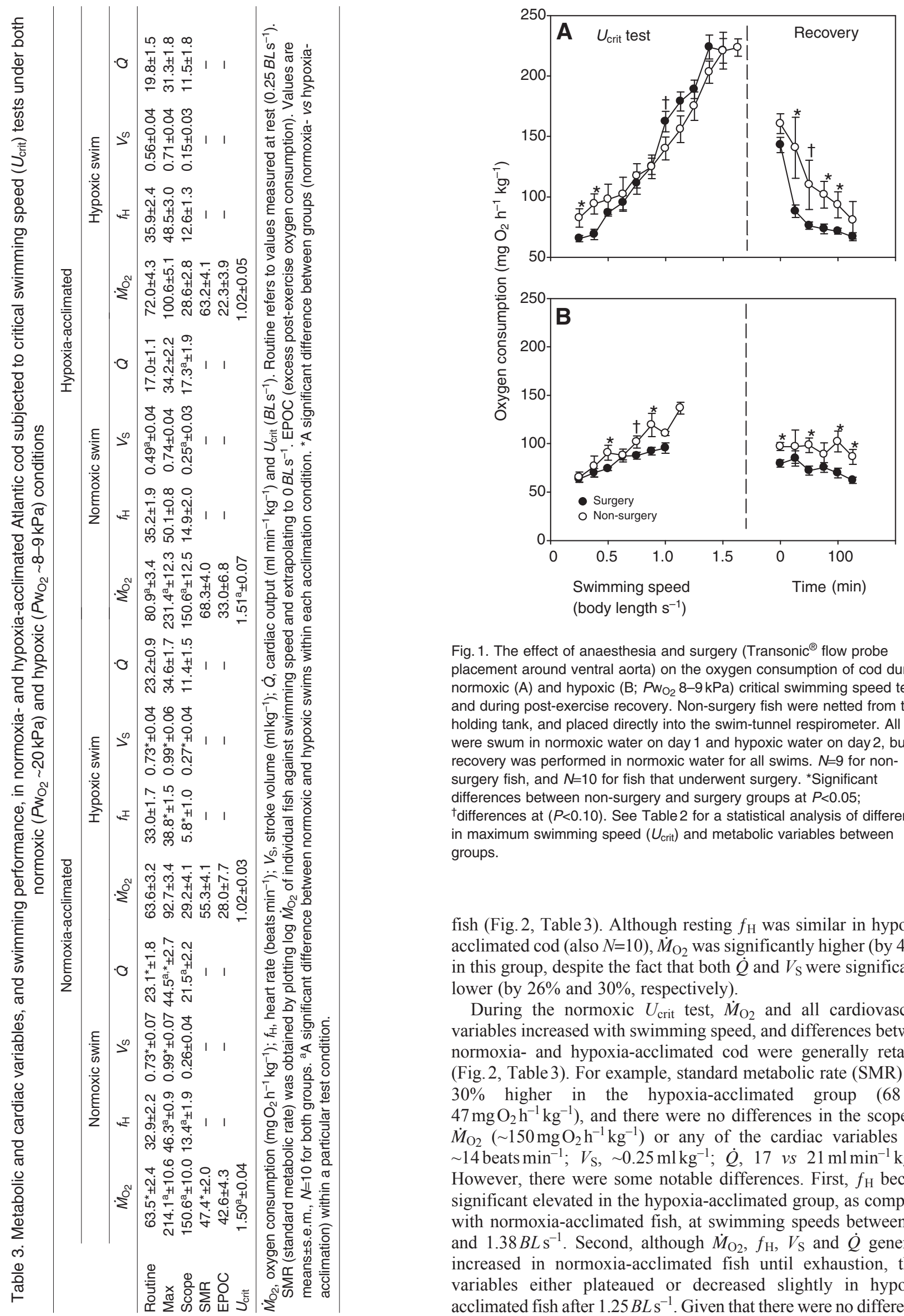

Fig. 1. The effect of anaesthesia and surgery $\left(\right.$ Transonic $^{\circledR}$ flow probe placement around ventral aorta) on the oxygen consumption of cod during normoxic (A) and hypoxic (B; $\mathrm{PW}_{\mathrm{O}_{2}} 8-9 \mathrm{kPa}$ ) critical swimming speed tests, and during post-exercise recovery. Non-surgery fish were netted from their holding tank, and placed directly into the swim-tunnel respirometer. All fish were swum in normoxic water on day 1 and hypoxic water on day 2, but recovery was performed in normoxic water for all swims. $N=9$ for nonsurgery fish, and $N=10$ for fish that underwent surgery. *Significant differences between non-surgery and surgery groups at $P<0.05$; ${ }^{\dagger}$ differences at $(P<0.10)$. See Table 2 for a statistical analysis of differences in maximum swimming speed $\left(U_{\text {crit }}\right)$ and metabolic variables between groups.

fish (Fig. 2, Table 3). Although resting $f_{\mathrm{H}}$ was similar in hypoxiaacclimated cod (also $N=10$ ), $\dot{M}_{\mathrm{O}_{2}}$ was significantly higher (by $40 \%$ ) in this group, despite the fact that both $\dot{Q}$ and $V_{\mathrm{S}}$ were significantly lower (by $26 \%$ and $30 \%$, respectively).

During the normoxic $U_{\text {crit }}$ test, $\dot{M}_{\mathrm{O}_{2}}$ and all cardiovascular variables increased with swimming speed, and differences between normoxia- and hypoxia-acclimated cod were generally retained (Fig. 2, Table 3). For example, standard metabolic rate (SMR) was $30 \%$ higher in the hypoxia-acclimated group (68 vs $47 \mathrm{mg} \mathrm{O}_{2} \mathrm{~h}^{-1} \mathrm{~kg}^{-1}$ ), and there were no differences in the scope for $\dot{M}_{\mathrm{O}_{2}}\left(\sim 150 \mathrm{mg} \mathrm{O}_{2} \mathrm{~h}^{-1} \mathrm{~kg}^{-1}\right)$ or any of the cardiac variables $\left(f_{\mathrm{H}}\right.$, $\sim 14$ beats $\min ^{-1} ; V_{\mathrm{S}}, \sim 0.25 \mathrm{ml} \mathrm{kg}^{-1} ; \dot{Q}, 17$ vs $\left.21 \mathrm{ml} \mathrm{min}^{-1} \mathrm{~kg}^{-1}\right)$. However, there were some notable differences. First, $f_{\mathrm{H}}$ became significant elevated in the hypoxia-acclimated group, as compared with normoxia-acclimated fish, at swimming speeds between 1.0 and $1.38 B \mathrm{Bs}^{-1}$. Second, although $\dot{M}_{\mathrm{O}_{2}}, f_{\mathrm{H}}, V_{\mathrm{S}}$ and $\dot{Q}$ generally increased in normoxia-acclimated fish until exhaustion, these variables either plateaued or decreased slightly in hypoxiaacclimated fish after $1.25 \mathrm{BL} \mathrm{s}^{-1}$. Given that there were no differences 

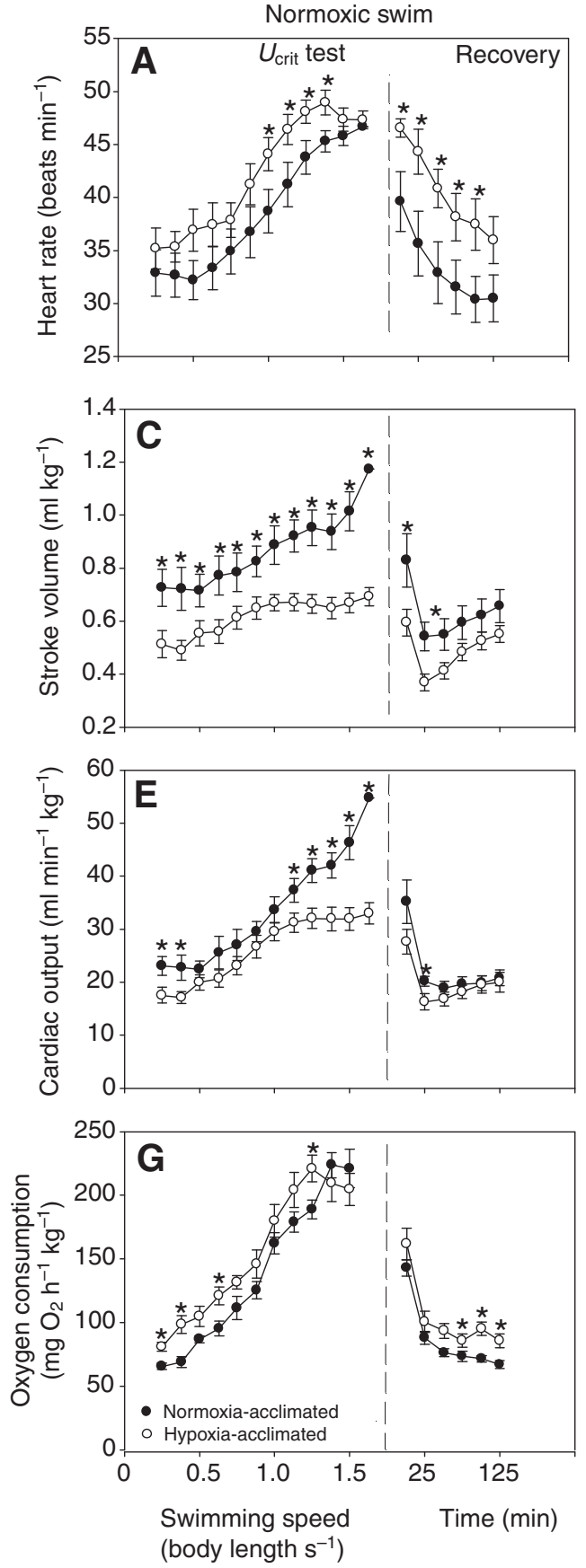
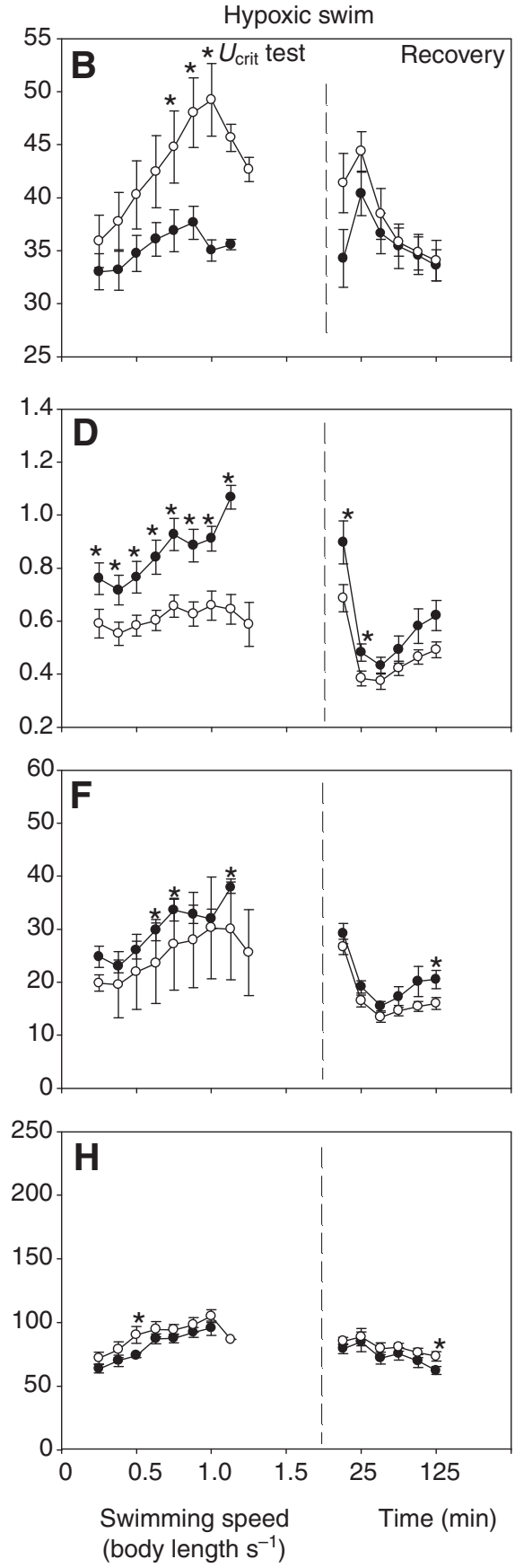

Fig. 2. (A,B) Heart rate, (C,D) stroke volume, $(E, F)$ cardiac output and $(\mathrm{G}, \mathrm{H})$ oxygen consumption in normoxia- $(N=10)$ and hypoxia-acclimated $(N=12) \mathrm{cod}$ during critical swimming speed $\left(U_{\text {crit }}\right)$ tests, and during post-exercise recovery. All fish were swum in normoxic water on day 1 and hypoxic water on day 2 , but recovery was performed in normoxic water for all swims. *A significant difference $(P<0.05)$ between the normoxia- and hypoxia-acclimated groups at a particular swimming speed. in metabolic scope or the scope for cardiac variables, it was not surprising that $U_{\text {crit }}\left(\sim 1.5 B L \mathrm{~s} \mathrm{~s}^{-1}\right)$ was identical in the two groups.

During recovery from the $U_{\text {crit }}$ test, $\dot{M}_{\mathrm{O}_{2}}$ fell rapidly in both groups, and there was no significant difference in EPOC $(P=0.31$; Table 3 ), although it was $30 \%$ higher in the normoxia-acclimated group. Interestingly, the post-exercise pattern of change for $f_{\mathrm{H}}$ was different than for $\dot{Q}$ and $V_{\mathrm{S}}$. The $f_{\mathrm{H}}$ fell slowly after the cod were exhausted, whereas both $\dot{Q}$ and $V_{\mathrm{S}}$ decreased rapidly (i.e. within $25 \mathrm{~min}$ ) to values comparable to, or below, routine levels and then rebounded (Fig. 2).

\section{Graded hypoxia and the hypoxic $\boldsymbol{U}_{\text {crit }}$ test}

At the start of the second day (i.e. at $P_{\mathrm{W}_{2} 2} 21 \mathrm{kPa}$; Fig. 3) $\dot{M}_{\mathrm{O} 2}$ and values for cardiac function were very similar to those measured at the beginning of day 1 (i.e. prior to the normoxic $U_{\text {crit }}$ test, Fig. 2), and the differences between groups were maintained. For example, routine $\dot{M}_{\mathrm{O}_{2}}$ was slightly (by $\sim 10 \%$ ) higher, and $\dot{Q}$ and $V_{\mathrm{S}}$ were again significantly lower (by $\sim 22$ and 30\%, respectively), in the hypoxiaacclimated group (Fig. 3). There were very few changes in $\dot{M}_{\mathrm{O}_{2}}$ or cardiovascular variables as water $\mathrm{O}_{2}$ partial pressure was lowered from $21 \mathrm{kPa}$ to $8-9 \mathrm{kPa}$. However, $f_{\mathrm{H}}$ and $\dot{Q}$ did increase slightly, and significantly, after $1 \mathrm{~h}$ of exposure to water of $8-9 \mathrm{kPa} \mathrm{O}_{2}$ in the normoxia-acclimated cod.

The pattern of change in $\dot{M}_{\mathrm{O}_{2}}$ and cardiac variables during the hypoxic $U_{\text {crit }}$ test was qualitatively similar to that seen during the normoxic swim (Fig. 2). However, $U_{\text {crit }}$ for both groups $\left(1.0 \mathrm{BL} \mathrm{s}{ }^{-1}\right)$ was only approximately two-thirds of that measured during normoxia $\left(1.5 B L \mathrm{~s}^{-1}\right)$, and this diminished swimming performance 

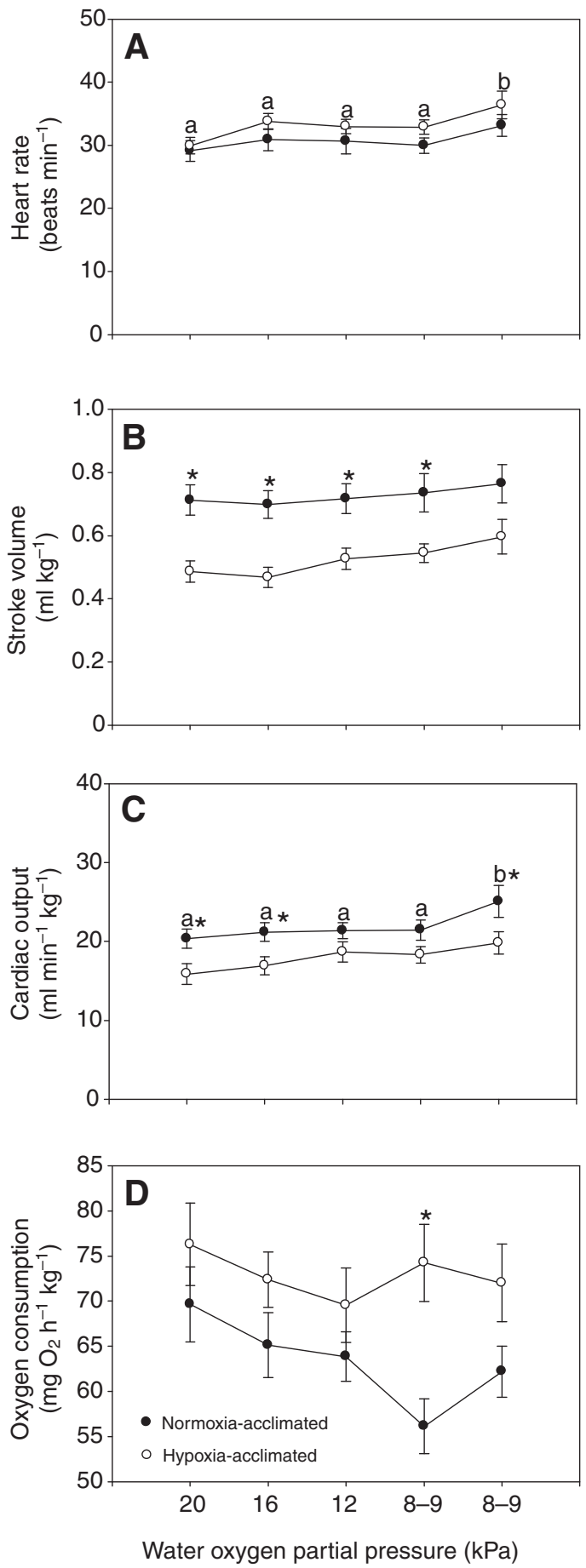

Fig. 3. Cardiac function and metabolism when normoxia- and hypoxiaacclimated cod were exposed to graded hypoxia. (A) Heart rate, (B) stroke volume, (C) cardiac output and (D) oxygen consumption. Oxygen levels were dropped from a $P \mathrm{~W}_{\mathrm{O}_{2}}$ of $20 \mathrm{kPa}$ to $16 \mathrm{kPa}$ in the first hour, from 16 to $12 \mathrm{kPa}$ in the second hour and finally from 12 to $8-9 \mathrm{kPa}$ in the third hour. Dissimilar letters indicate significant $(P<0.05)$ differences from $20 \mathrm{kPa}$ and other oxygen levels within the normoxic group. *Indicates values significantly $(P<0.05)$ different between normoxia- and hypoxia-acclimated fish at a particular $P \mathrm{~W}_{\mathrm{O}_{2}}$.

was associated with important differences in how cardiorespiratory variables in normoxia- and hypoxia-acclimated cod responded to the exercise regimen. First, as compared with the normoxic swim, maximum $\dot{M}_{\mathrm{O}_{2}}$ was greatly reduced in both groups (214 and $231 \mathrm{mg} \mathrm{O}_{2} \mathrm{~h}^{-1} \mathrm{~kg}^{-1}$ vs 93 and $101 \mathrm{mg} \mathrm{O}_{2} \mathrm{~h}^{-1} \mathrm{~kg}^{-1}$ ), and this resulted in a dramatically reduced metabolic scope (to $\sim 30 \mathrm{mg} \mathrm{O}_{2} \mathrm{~h}^{-1} \mathrm{~kg}^{-1}$ ). Second, although the scope for $\dot{Q}$ was reduced to a similar degree in both groups (to $\sim 11.5 \mathrm{ml} \mathrm{min}^{-1} \mathrm{~kg}^{-1}$ ) when the cod were swum under hypoxic conditions as compared with normoxia, the reason for the reduced scope for $\dot{Q}$ was different. In the normoxiaacclimated group, the scope for $\dot{Q}$ was diminished because the scope for $f_{\mathrm{H}}$ was reduced by $50 \%$ (normoxia 13.4 beats $\mathrm{min}^{-1}$; hypoxia 5.8 beats $\mathrm{min}^{-1}$ ). In contrast, the scope for $V_{\mathrm{S}}$ fell from 0.25 to $0.15 \mathrm{ml} \mathrm{kg}^{-1}$ in the hypoxia-acclimated group when the cod were swum at an oxygen level of $8-9 \mathrm{kPa}$ (Table 3 ).

During recovery from the hypoxic $U_{\text {crit }}$ test, the pattern of change in $\dot{M}_{\mathrm{O} 2}, \dot{Q}$ and $V_{\mathrm{S}}$ was similar to that observed after the normoxic swim. However, the pattern of change in $f_{\mathrm{H}}$ was quite different. Heart rate increased in both groups between 0 and $25 \mathrm{~min}$ postexercise, before declining to pre-swim levels (Fig. 2). This was probably due to the fact that these fish were recovered in normoxic, not hypoxic water. As with the normoxic swim, there was no difference in EPOC values between the two groups. However, for both groups, EPOC was $\sim 35 \%$ lower than the values for cod swum under normoxic conditions (Table 3 ).

\section{Relationship between oxygen consumption and cardiac output}

During the normoxic swim (Fig.4A) there was a strong linear relationship between cardiac output and oxygen consumption in both the normoxic $\left(r^{2}=0.97\right)$ and hypoxic groups $\left(r^{2}=0.95\right)$. However, the relationship for the hypoxia-acclimated fish was shifted decidedly upwards, and this resulted in a substantially greater $\dot{M}_{\mathrm{O} 2}$ for a given $\dot{Q}$ in hypoxia- as compared with normoxiaacclimated fish. There was no clear relationship between $\dot{M}_{\mathrm{O}_{2}}$ and $\dot{Q}$ when the fish were exposed to graded hypoxia. However, the $\dot{M}_{\mathrm{O}_{2}}$ of hypoxia-acclimated fish was generally above that of the normoxia-acclimated fish, and this elevated level of $\dot{M}_{\mathrm{O}_{2}}$ was achieved at reduced levels of $\dot{Q}$ (Fig. 4B). Finally, although the relationship between $\dot{M}_{\mathrm{O}_{2}}$ and $\dot{Q}$ was not as strong during the hypoxic swim $\left(r^{2}=0.83\right.$ and 0.84$)$, and the data for the hypoxiaacclimated group was much more variable, it was again apparent that the hypoxia-acclimated fish consumed more $\mathrm{O}_{2}$ for a given cardiac output (Fig. 4C).

\section{DISCUSSION}

The cod in this study were swum to exhaustion, first under normoxia, and then at a $P_{\mathrm{W}_{2}}$ of $\sim 8-9 \mathrm{kPa}$ after being allowed to recover from the initial $U_{\text {crit }}$ test for $\sim 24 \mathrm{~h}$. This experimental design has some limitations. Most importantly, the possibility that different degrees of recovery from surgery $(18 v s \sim 42 \mathrm{~h}$ ) or effects related to the initial $U_{\text {crit }}$ test, might have obscured some effects of acute hypoxia on swimming performance, cardiac function and metabolic capacity. We believe that these were minimal given how closely our data fit with those in the literature, that fish recover quickly (within $2 \mathrm{~h}$ ) from exhaustive exercise under normoxic conditions (Jain and Farrell, 2003; Jain et al., 1998), and that the reduction in $U_{\text {crit }}$ with acute hypoxia was similar in fish that were simply placed into the swim-tunnel (non-surgery) vs those that were implanted with flow probes (see below). Furthermore, it is unlikely that the experimental design significantly affected our major findings with respect to the effects of acclimation to hypoxia on cod cardiorespiratory function. This is because our results are very similar to those obtained in a later study where cod were given a graded hypoxic challenge $\sim 24 \mathrm{~h}$ after recovering from surgery 

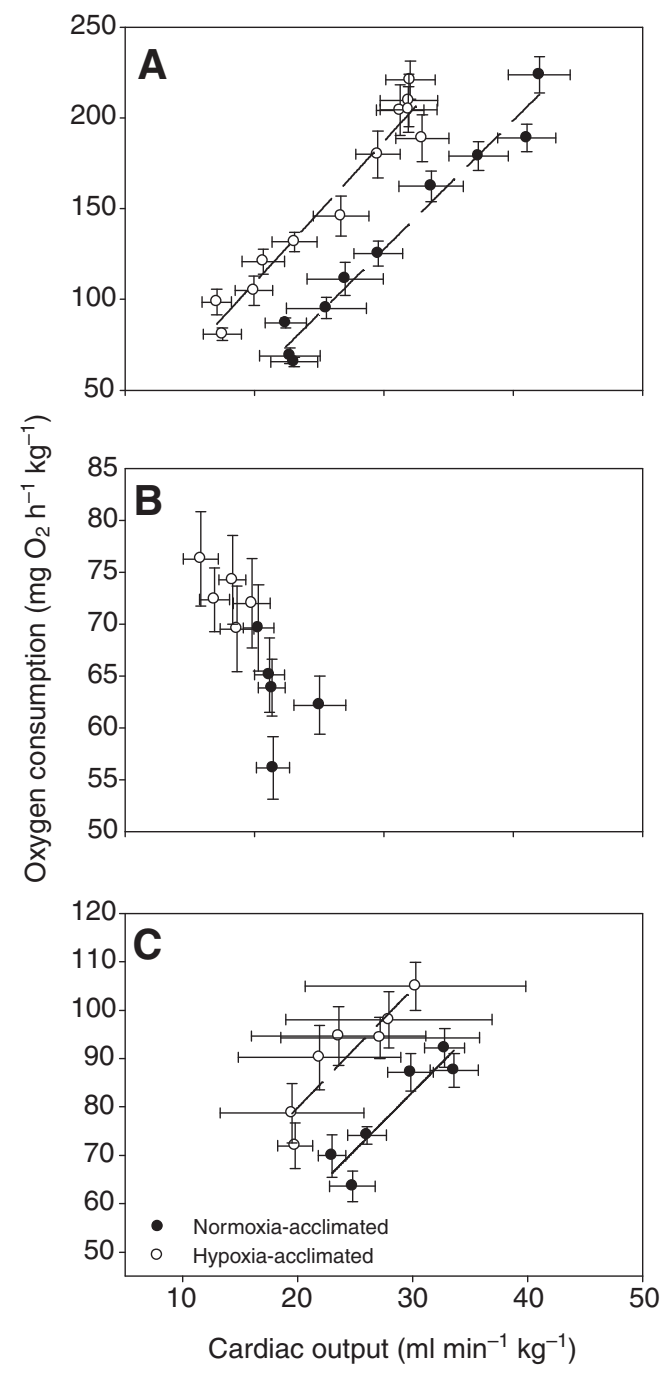

Fig. 4. Relationship between oxygen consumption and cardiac output in the normoxia- and hypoxia-acclimated cod during the normoxic $U_{\text {crit }}$ test (A), when exposed to graded hypoxia (B), and finally during the hypoxic $U_{\text {crit }}$ test $(C)$. Dashed lines define the linear regressions that were fitted to the data. Normoxic swim: normoxia-acclimated group $\left(y=7.1 x-85.48, r^{2}=0.97\right)$, hypoxia-acclimated group $\left(y=7.79 x-0.95, r^{2}=0.95\right)$. Hypoxic swim: normoxia-acclimated group $\left(y=2.40 x+11.14, r^{2}=0.84\right)$, hypoxia-acclimated group $\left(y=2.46 x+30.62, r^{2}=0.83\right)$

(L.H.P. and A.K.G., unpublished) and to those recently reported by Lamarche et al. (Lamarche et al., 2009).

\section{Effects of surgery}

The reduction in normoxic swimming performance (from 1.74 to $1.5 \mathrm{Bl} \mathrm{s}^{-1}$ ) associated with surgery and/or anaesthesia was not unexpected (see Butler et al., 1989; Campbell et al., 2004; Bell and Eggleston, 2005). Nonetheless, it is difficult to ascribe a definitive cause for the diminished $U_{\text {crit }}$ under normoxic conditions. This is because Butler et al. (Butler et al., 1989) report that $U_{\text {crit }}$ in cod is diminished by $13.5 \%$ following sham surgery (a similar decrease to that reported here, $14 \%$ ), and thus the presence of the flow probe and/or drag associated with the probe lead are unlikely to explain the reduced $U_{\text {crit }}$ in fish that underwent surgery. Furthermore, maximum $\dot{M}_{\mathrm{O}_{2}}$ and metabolic scope were similar between groups $\left(\sim 220\right.$ and $150 \mathrm{mg} \mathrm{O}_{2} \mathrm{~h}^{-1} \mathrm{~kg}^{-1} ; \sim 198$ and $135 \mathrm{mg} \mathrm{O}_{2} \mathrm{~h}^{-1} \mathrm{~kg}^{-0.8}$;
Table 1), and the scope for $\dot{Q}\left(21.5 \mathrm{mlmin}^{-1} \mathrm{~kg}^{-1}\right)$ was almost identical to that obtained for cod fitted with Doppler flow probes that were subjected to a $U_{\text {crit }}$ test following at least $48 \mathrm{~h}$ of recovery [23 $\mathrm{ml} \mathrm{min}^{-1} \mathrm{~kg}^{-1}$; Webber et al. (Webber et al. 1998)]. There are, however, two potential explanations. Cod in poor condition (condition factor 0.68) start burst-coast swimming (i.e. switch to a mix of aerobic and anaerobic powered swimming) at lower speeds, and become exhausted at a reduced $U_{\text {crit }}$ (Lapointe et al., 2006). However, we feel that an earlier initiation of burst-coast swimming is unlikely in this study as there were no significant $(P<0.05)$ differences in $\dot{M}_{\mathrm{O}_{2}}$ between the two groups of fish at swimming speeds above $0.38 B L \mathrm{~s}^{-1}$; this finding suggesting that the cost of transport was similar between the two groups. In addition, EPOC [an index of the non-aerobic costs of exercise (Lee et al., 2003)] was significantly lower in the surgery group. This latter result suggests that $U_{\text {crit }}$ was reduced not because burst-coast swimming was initiated at a lower velocity, but because the number or intensity of burst-coast events prior to exhaustion was diminished. Such a reduction in swimming effort associated with recovery from anaesthesia/surgery would be consistent with the conclusions of McFarlane and McDonald (MacFarlane and MacDonald, 2002) and Peake and Farrell (Peake and Farrell, 2006). These authors indicate that the cessation of activity and decreased swimming performance in $U_{\text {crit }}$ tests is often a behavioural response (i.e. fish are disinclined to perform).

\section{Effects of acute hypoxia and acclimation to hypoxia: measurements at rest}

Acclimation to chronic hypoxia $(\sim 8 \mathrm{kPa})$ resulted in elevated routine (i.e. measured at $0.25 \mathrm{BL} \mathrm{s}^{-1}$ ) and standard metabolic rates (Table3, Fig. 2) in normoxia as compared with normoxia-acclimated cod, despite lower values of $V_{\mathrm{S}}$ and $\dot{Q}\left(0.49 v s 0.73 \mathrm{ml} \mathrm{kg}^{-1}\right.$ and $17.0 v \mathrm{~s}$ $21.3 \mathrm{ml} \mathrm{min}^{-1} \mathrm{~kg}^{-1}$, respectively). The higher routine $\dot{M}_{\mathrm{O}_{2}}$ in hypoxiaacclimated cod contrasts with the findings of Bushnell et al. (Bushnell et al., 1984) who reported that acclimation to hypoxia did not influence, or significantly reduced, normoxic $\dot{M}_{\mathrm{O} 2}$ values in resting rainbow trout. The disparity in results between our study and that of Bushnell et al. (Bushnell et al., 1984) could be related to methodological differences. Bushnell et al. (Bushnell et al., 1984) only acclimated their trout to hypoxia for 3 weeks, the level of hypoxia during acclimation $(\sim 5.6 \mathrm{kPa})$ was more severe than utilized in the present study, and the hypoxia-acclimated trout were only allowed a brief period at normoxic levels of oxygen prior to measurements of $\dot{M}_{\mathrm{O}_{2}}$. However, it may also be due to inter-specific differences in how teleost fish are affected by chronic hypoxia. For example, Lomholt and Johansen (Lomholt and Johansen, 1979) report that carp (Cyprinus carpio) acclimated to a $P_{\mathrm{O}_{2}}$ of $4 \mathrm{kPa}$ for 4 weeks had a reduced $\dot{M}_{\mathrm{O}_{2}}$ when they were returned to high oxygen conditions, whereas Pichavant et al. (Pichavant et al., 2000) showed that acclimation to hypoxia (45 days at a $P_{\mathrm{O}_{2}} \sim 10 \mathrm{kPa}$ ) did not alter the routine $\dot{M}_{\mathrm{O}_{2}}$ of turbot (Scophthalmus maximus) at any water $P_{\mathrm{O}_{2}}$ level. This study did not attempt to elucidate the factors responsible for the elevated routine $\dot{M}_{\mathrm{O}_{2}}$ in hypoxia-acclimated fish. However, it is unlikely that the higher $\dot{M}_{\mathrm{O}_{2}}$ was stress related. This is because circulating catecholamines in resting hypoxia-acclimated cod at $18-24 \mathrm{~h}$ post surgery are $\leq 5 \mathrm{nmoll}^{-1}$ when measured under normoxia, and similar to those measured in normoxia-acclimated fish (L.H.P. and A.K.G., unpublished).

Standard and routine metabolic rates decreased slightly (nonsurgery and hypoxia-acclimated fish) or were unchanged (normoxiaacclimated group) when the cod were acutely exposed to a $P_{\mathrm{W}_{2}}$ of $8-9 \mathrm{kPa}$ (Tables 2 and 3 ). These results are consistent with recent 
data on juvenile cod at $10^{\circ} \mathrm{C}$ where both trends have been reported prior to fish reaching their critical oxygen tension (Steffensen et al., 1994; Schurmann and Steffensen, 1997; Gamperl et al., 2009). When normoxia-acclimated cod were exposed to acute hypoxia, $V_{\mathrm{S}}$ did not change significantly, although $\dot{Q}$ and $f_{\mathrm{H}}$ did increase slightly after $1 \mathrm{~h}$ at $8-9 \mathrm{kPa}$, as compared with the value recorded at the start of day 2 (Table 3, Fig. 3). The lack of hypoxic bradycardia, and a concomitant increase in $V_{\mathrm{S}}$, in this study as compared with that of Fritsche and Nilsson (Fritsche and Nilsson, 1989) is most likely due to the depth of hypoxia, as: (1) Fritsche and Nilsson exposed their cod to $\sim 5 \mathrm{kPaO}_{2}$ as compared to $8-9 \mathrm{kPa}$ in the present study; (2) the $S_{\text {crit }}$ for Atlantic cod (i.e. the water $\mathrm{O}_{2}$ saturation at which they transitioned from being an oxyregulator to an oxyconformer) at $10^{\circ} \mathrm{C}$ (Schurmann and Steffensen, 1997; Gamperl et al., 2009) is at or below the lowest level of hypoxia used in this study; and (3) Petersen and Gamperl (L.H.P. and A.K.G., unpublished) have shown that $f_{\mathrm{H}}$ falls (and $V_{\mathrm{S}}$ increases) rapidly in normoxia- and hypoxia-acclimated cod when $P_{\mathrm{W}_{2}}$ falls below $\sim 5 \mathrm{kPa}\left(f_{\mathrm{H}}\right.$ and $V_{\mathrm{S}}$ in normoxiaacclimated cod $\sim 20$ beats $\mathrm{min}^{-1}$ and $1.3 \mathrm{ml} \mathrm{kg}^{-1}$, respectively, at $2.7 \mathrm{kPa}$ ). However, we cannot exclude the possibility that the rapid induction of hypoxia in the Fritsche and Nilsson study (Fritsche and Nilsson, 1989) (i.e. over $\sim 60 \mathrm{~s}$ ), vs exposure to graded hypoxia over a period of $3 \mathrm{~h}$ (present study), contributed to the contrasting effects of hypoxia on $f_{\mathrm{H}}$ between the two studies.

\section{Effects of acute hypoxia: exercise}

When the two normoxia-acclimated groups (i.e. surgery and nonsurgery) were exposed to a $P \mathrm{~W}_{\mathrm{O}_{2}}$ of $8-9 \mathrm{kPa}, U_{\text {crit }}$ was reduced by 33 and $29 \%$, respectively. This decrease in $U_{\text {crit }}$ is very similar to that reported by Dutil et al. (Dutil et al., 2007) for $7^{\circ} \mathrm{C}$ cod swum at $8.5 \mathrm{kPa}\left(1.72\right.$ vs $\left.1.26 \mathrm{BL} \mathrm{s}^{-1}\right)$, and comparable to those for rainbow trout $[\sim 25 \%$ at $5.6 \mathrm{kPa}$; Bushnell et al. (Bushnell et al., 1984)] and coho salmon [Oncorhynchus kisutch; $27 \%$ at $\sim 8.5 \mathrm{kPa}$; Dahlberg et al. (Dahlberg et al., 1968)] swum at 15 and $20^{\circ} \mathrm{C}$, respectively. However, it is much greater than that recorded for largemouth bass (Micropterus salmoides) at $25^{\circ} \mathrm{C}(10 \%$ at $\sim 8.5 \mathrm{kPa})$ (Dahlberg et al., 1968) and mullaway (Argyrosomus japonicus) at $21-23^{\circ} \mathrm{C}(17 \%$ at both $\sim 10$ and $5 \mathrm{kPa}$ ) (Fitzgibbon et al., 2007). When combined, these data suggest that there are considerable inter-specific differences in the sensitivity of swimming performance to reduced oxygen levels, and that this variation is related to the likelihood that a species will encounter hypoxic conditions during its life history. For example, most salmonids inhabit well-aerated fluvial environments and cod normally avoid water oxygen levels less than $9 \mathrm{kPa}(40-45 \%$ air saturation) (Claireaux et al., 2005). By contrast, largemouth bass prefer shallow, warm, weedy areas (Heidinger, 1975) and the mullaway spends its early life in estuaries (Fitzgibbon et al., 2007), both environments where water quality and oxygenation can vary considerably.

It is clear that reduced metabolic scope (by 55 and $80 \%$ in nonsurgery and surgery groups, respectively; Table 2) restricted the swimming performance of our normoxia-acclimated cod during acute hypoxic exposure; and that this was, in large part, related to a diminished maximum cardiac performance. The dependence of fish swimming performance on metabolic scope is well established (e.g. Fry, 1971; Arnott et al., 2006; Chatelier et al., 2006), and the magnitude of the decreases in metabolic scope when the cod were swum under hypoxic conditions are consistent with other studies that have examined the relationship between metabolic scope and reduced water oxygen levels in this species. For example, at a $P_{\mathrm{W}_{2}}$ of $8-10 \mathrm{kPa}$ cod forced to swim in respirometers to $U_{\text {crit }}$ show reductions in metabolic scope ranging from $65-75 \%$ (Claireaux et al., 1995; Dutil et al., 2007), whereas scope calculated on free-living fishes using limiting oxygen concentration curves (Claireaux and Lagardére, 1999) falls by $\sim 53 \%$ (Claireaux et al., 2000). Furthermore, myocardial performance is a primary factor limiting metabolic rate and $U_{\text {crit }}$ in many active teleosts (Farrell, 2002; Claireaux et al., 2005; Clark et al., 2005), and maximum $\dot{Q}$ was reduced by $47 \%$ when normoxia-acclimated cod were swum under hypoxic conditions. Although a diminished maximum $\dot{Q}$ under hypoxic as compared with normoxic conditions (from 45.5 to $34.6 \mathrm{ml} \mathrm{min}^{-1} \mathrm{~kg}^{-1}$ ) was not unexpected (e.g. Hanson et al., 2006), we were surprised to find that the reduction in $\dot{Q}$ was solely related to a lower maximum $f_{\mathrm{H}}$ (and scope for $f_{\mathrm{H}}$ ); maximum $V_{\mathrm{S}}$ reaching the same value as measured under normoxia $\left(0.99 \mathrm{ml} \mathrm{kg}^{-1}\right)$. This is because, in contrast to the rainbow trout (e.g. Faust et al., 2004; Gamperl et al., 2004), acute exposure of the in situ cod heart to severe hypoxia does not affect $f_{\mathrm{H}}$ during resting or maximum levels of cardiac performance (Petersen and Gamperl, 2010), and maximum $f_{\mathrm{H}}$ and scope for $f_{\mathrm{H}}$ were not different in hypoxiaacclimated cod when swum under hypoxic and normoxic conditions (Fig. 2, Table 3). Furthermore, it is unlikely that the lowered $f_{\mathrm{H}}$ was the result of the stimulation of branchial $\mathrm{O}_{2}$ receptors as this level of hypoxia $(8-9 \mathrm{kPa})$ did not elicit bradycardia under resting conditions. This raises the distinct possibility that venous $\mathrm{O}_{2}$ receptors located at or before the heart, as proposed by Barrett and Taylor (Barrett and Taylor, 1984), were stimulated by severe hypoxemia associated with exercise under hypoxic conditions and mediated a reduction in heart rate through the efferent limb of the cardiac vagus.

\section{Effects of acclimation to hypoxia: exercise}

Cod chronically acclimated to moderate hypoxia $(8-9 \mathrm{kPa})$ had values of maximum $\dot{M}_{\mathrm{O}_{2}}$, metabolic scope and $U_{\text {crit }}$ under normoxia and hypoxia that were not significantly different from those measured in normoxia-acclimated fish (Table 3). These results are in agreement with the results of Bushnell et al. (Bushnell et al., 1984) and Kutty (Kutty, 1968), who showed that neither the swimming speed-oxygen consumption relationship or $U_{\text {crit }}$ values were altered when rainbow trout and goldfish, respectively, were acclimated to hypoxic conditions. Collectively, these data indicate that the swimming performance of fish living in areas impacted by prolonged hypoxia will be diminished significantly, and that they may be more vulnerable to predation. This would be especially true if they encountered mammalian (e.g. seals, cetaceans) or avian (e.g. diving birds) predators whose aerobic requirements are not dependent upon water oxygen levels.

The similar values for metabolic variables and $U_{\text {crit }}$ in the two groups was surprising given that maximum $\dot{Q}$ was lower in hypoxiaacclimated fish at all swimming speeds in both $U_{\text {crit }}$ tests, and that maximum $\dot{Q}$ during the normoxic swim test was $23 \%$ lower in hypoxia-acclimated cod as compared with normoxia-acclimated individuals due to diminished values for $V_{\mathrm{S}}$ (Fig. 2, Table 3). This apparent discrepancy is resolved, however, when the relationship between $\dot{Q}$ and oxygen consumption is examined for the two groups (Fig.4). During both the normoxic and hypoxic swims, hypoxiaacclimated cod consumed more oxygen for a given cardiac output. For example, at a $\dot{Q}$ of $30 \mathrm{ml} \mathrm{min}^{-1} \mathrm{~kg}^{-1}$, hypoxia-acclimated cod consumed $\sim 185 \mathrm{mlO}_{2} \mathrm{~h}^{-1} \mathrm{~kg}^{-1}$ when swimming under normoxic conditions as compared with $\sim 130 \mathrm{ml} \mathrm{O}_{2} \mathrm{~h}^{-1} \mathrm{~kg}^{-1}$ in normoxiaacclimated fish. This upward shift in the relationship between $\dot{Q}$ and oxygen consumption following long-term acclimation to moderate hypoxia was probably due to increases in both blood oxygen transport capacity and tissue $\mathrm{O}_{2}$ extraction efficiency 
because: (1) several authors have reported increases in haematocrit, blood haemoglobin levels and/or haemoglobin oxygen affinity in response to hypoxia acclimation (e.g. Bushnell et al., 1984; Driedzic et al., 1985; Timmerman and Chapman, 2004); and (2) subsequent experiments in our lab have shown that tissue $\mathrm{O}_{2}$ extraction efficiency is significantly enhanced (by $15 \%$ ) in hypoxia-acclimated cod under normoxic conditions, while blood haemoglobin levels are slightly or significantly (depending on water $P_{\mathrm{O}_{2}}$ ) higher in hypoxia-acclimated cod at rest (L.H.P. and A.K.G., unpublished). Furthermore, although cod heart function does not appear to be modulated by circulating catecholamines (Axelsson, 1988), these hormones activate $\mathrm{Na}^{+} / \mathrm{H}^{+}$exchange in cod red blood cells [and presumably improve blood oxygen carrying capacity (Berenbrink and Bridges, 1994)], and hypoxia-acclimated cod have significantly higher stress-induced catecholamine levels (Petersen and Gamperl, 2010).

One of the major findings of this study was that hypoxiaacclimated cod had significantly lower values for resting and maximum $V_{\mathrm{S}}$ and $\dot{Q}$ in both swim tests, and a significantly lower scope for $V_{\mathrm{S}}$ when swum under hypoxic conditions, as compared with the normoxia-acclimated group (Fig. 2, Table 3). Given that neither cod heart size or relative ventricular mass (RVM) are affected by exposure to chronic hypoxia (Petersen and Gamperl, 2010), the most obvious explanation for this diminished cardiac function is that long-term acclimation to hypoxia had a direct negative effect on the heart's pumping capacity. Indeed, this hypothesis is directly supported by the results of a recent study that investigated the effects of chronic hypoxia on in situ cardiac function (present study). These authors showed that acclimation to hypoxia reduced maximum in situ $\dot{Q}$ and $V_{\mathrm{S}}$ by 19 and $28 \%$, respectively, under oxygenated conditions. However, whether this reduced pumping capacity is due myocardial stunning (Bolli and Marban, 1999), myocardial necrosis (e.g. Lennard and Huddart, 1992) or remodelling of the myocardium that resulted in a smaller ventricular lumen and outflow tract (Marques et al., 2008) has not been resolved.

Hypoxia-acclimated cod were able to increase $f_{\mathrm{H}}$ during the hypoxic swim to levels measured during normoxia (Fig.2, Table 3). This resulted in them having a significantly greater scope for $f_{\mathrm{H}}$ (12.6 vs 5.8 beats $\mathrm{min}^{-1}$ ), and allowed them to achieve the same maximum $\dot{Q}$, as compared with normoxia-acclimated fish when swum at $8-9 \mathrm{kPa} \mathrm{O}_{2}$. The mechanism(s) resulting in the differential regulation of $f_{\mathrm{H}}$ in the two groups when swum under hypoxic conditions cannot be ascertained from the present study or the literature. However, this result, in combination with recent data showing that rainbow trout at $24^{\circ} \mathrm{C}$ can maintain $\dot{Q}$ even when $f_{\mathrm{H}}$ is halved using the pharmacological agent zatebradine (Gamperl et al., 2007), highlights the tremendous plasticity in how fish cardiorespiratory physiology responds to environmental challenges and that our understanding of control mechanisms that mediate myocardial function and adaptation in this taxa is far from complete.

\section{Conclusion}

In this study we made the first measurements of fish cardiorespiratory function during exercise under hypoxia $(8-9 \mathrm{kPa}$ $\mathrm{O}_{2}$ ), and of how acclimation to this same level of hypoxia for 6-12 weeks influenced resting and exercise-induced in vivo cardiac function under both hypoxic and normoxic conditions. These studies revealed that: (1) when cod were swum under hypoxic conditions cardiac function was diminished, and this was associated with reduced aerobic scope, and a $\sim 30 \%$ lower $U_{\text {crit }}$; (2) acclimation to hypoxia does not improve the cod's swimming capacity, maximum metabolic rate or scope for activity when swum to $U_{\text {crit }}$ under either normoxic or hypoxic conditions; and (3) although the resting and maximal cardiac output of hypoxia-acclimated cod were diminished due to a reduced $V_{\mathrm{S}}$, this does not significantly affect the swimming speed $-\mathrm{O}_{2}$ consumption relationship, maximum $\dot{M}_{\mathrm{O}_{2}}$ or aerobic scope. These results offer novel insights into how cod cardiorespiratory physiology is impacted by short-term and prolonged exposure to environmental hypoxia. Furthermore, they provide indirect evidence that venous $\mathrm{O}_{2}$ receptors may be important in regulating cardiac function in fishes, and are another important example of how incredibly flexible cardiac function, and its control, is in fishes. However, the fact that these experiments were performed with hatchery-reared (as opposed to wild) fish, and the paucity of data on the effects of exposure to hypoxia on fish cardiorespiratory physiology, leaves numerous questions unanswered. These include: to what extent are reductions in maximal exercise and cardiac pumping capacity in fish following exposure to hypoxia related to a species life history and/or hypoxia tolerance? Is the diminished pumping capacity of the cod heart following acclimation to hypoxia a consequence of myocardial damage or remodelling? What mechanisms allowed the cod's maximum oxygen consumption to be maintained following acclimation to hypoxia despite a considerable reduction in cardiac pumping capacity?

\section{ACKNOWLEDGEMENTS}

This research was funded by a Natural Sciences and Engineering Research Council of Canada Discovery Grant to A.K.G. and a Memorial University of Newfoundland (MUN) graduate fellowship to L.H.P. We thank Terry Harris for his electronics expertise, MUN technical services for manufacturing several pieces of equipment used in this study, Darrell Green for taking and analysing the water quality samples and Danny Boyce and the Atlantic Innovation Fund for providing the experimental fish.

\section{REFERENCES}

Arnott, S. A., Chiba, S. and Conover, D. O. (2006). Evolution of intrinsic growth rate: metabolic costs drive trade-offs between growth and swimming performance in Menidia menidia. Evolution 60, 1269-1278.

Axelsson, M. (1988). The importance of nervous and humoral mechanisms in the control of cardiac performance in the Atlantic cod Gadus morhua at rest and during non-exhaustive exercise. J. Exp. Biol. 137, 287-303.

Barrett, D. J. and Taylor, E. W. (1984). Changes in heart rate during progressive hyperoxia in the dogfish Scyliorhinus canicula L.: evidence for a venous oxygen receptor. Comp. Biochem. Physiol. 78, 697-703.

Bell, G. W. and Eggleston, D. B. (2005). Species-specific avoidance responses by blue crabs and fish to chronic and episodic hypoxia. Mar. Biol. 146, 761-770.

Berenbrink, M. and Bridges, C. R. (1994). Catecholamine-activated sodium/proton exchange in the red blood cells of the marine teleost Gadus morhua. J. Exp. Biol. 192, 253-267.

Bolli, R. and Marban, E. (1999). Molecular and cellular mechanisms of myocardial stunning. Physiol. Rev. 79, 609-634.

Breitburg, D. (2002). Effects of hypoxia, and the balance between hypoxia and enrichment, on costal fishes and fisheries. Estuaries 25, 767-781.

Brett, J. R. (1964). The respiratory metabolism of swimming performance of young sockeye salmon. J. Fish. Res. Bd. Can. 21, 1183-1226.

Burleson, M. L., Carlton, A. L. and Silva, P. E. (2002). Cardioventilatory effects of acclimatization to aquatic hypoxia in channel catfish. Resp. Physiol. Neurobiol. 131, 223-232.

Bushnell, P. G., Steffensen, J. F. and Johansen, K. (1984). Oxygen consumption and swimming performance in hypoxia-acclimated rainbow trout, Salmo gairdneri. J. Exp. Biol. 113, 225-235.

Butler, P. J., Taylor, E. W., Capra, M. F. and Davison, W. (1979). The effect of hypoxia on the levels of circulating catecholamines in the dogfish Scyliorhinus canicula. J. Comp. Physiol. 127, 325-330.

Butler, P. J., Axelsson, M., Ehrenström, F., Metcalfe, J. D. and Nilsson, S. (1989). Circulating catecholamines and swimming performance in the Atlantic cod, Gadus morhua. J. Exp. Biol. 141, 377-387.

Campbell, H. A., Taylor, E. W. and Egginton, S. (2004). The use of power spectral analysis to determine cardiorespiratory control in the short-horned sculpin Myxocephalus scorpius. J. Exp. Biol. 207, 1969-1976.

Cech, J. J., Jr (1990). Respirometry. In Methods of fish Biology (ed. C. B. Schreck and P. B. Moyle). Bethesda, MD: American Fisheries Society.

Chabot, D. and Dutil, J. D. (1999). Reduced growth of Atlantic cod in non-lethal hypoxic conditions. J. Fish. Biol. 55, 472-491.

Chatelier, A., McKenzie, D. J., Prinet, A., Galois, R., Robin, J., Zambonino, J. and Claireaux, G. (2006). Associations between tissue fatty acid composition and physiological traits of performance and metabolism in the seabass (Dicentrarchus labrax). J. Exp. Biol. 209, 3429-3439.

Claireaux, G. and Lagardère, J. P. (1999). Influence of temperature, oxygen and salinity on the metabolism of the European sea bass. J. Sea. Res. 42, 157-168. 
Claireaux, G., Webber, D. M., Kerr, S. R. and Boutilier, R. G. (1995). Physiology and behaviour of free-swimming Atlantic cod (Gadus morhua) facing fluctuating salinity and oxygenation conditions. J. Exp. Biol. 198, 61-69.

Claireaux, G., Webber, D. M., Lagardère, J. P. and Kerr, S. R. (2000). Influence of water temperature and oxygenation on the aerobic metabolic scope of Atlantic cod (Gadus morhua). J. Sea Res. 44, 257-265.

Claireaux, G., McKenzie, D. J., Genge, A. G., Chatelier, A., Aubin, J. and Farrell, A. P. (2005). Linking swimming performance, cardiac pumping ability and cardiac anatomy in rainbow trout. J. Exp. Biol. 208, 1775-1784.

Clark, T. D. and Seymour, R. S. (2006). Cardiorespiratory physiology and swimming energetics of a high-energy-demand teleost, the yellowtail kingfish (Seriola lalandi). J. Exp. Biol. 209, 3940-3951.

Clark, T., Ryan, T., Ingram, B., Woakes, A., Butler, P. and Frappell, P. (2005). Factorial aerobic scope is independent of temperature and primarily modulated by heart rate in exercising Murray cod (Maccullochella peelii peelii). Physiol. Biochem. Zool. 78, 347-355.

Dahlberg, M. L., Shumway, D. L. and Doudoroff, O. (1968). Influence of dissolved oxygen and carbon dioxide on swimming performance of largemouth bass and coho salmon. J. Fish. Res. Bd. Can. 25, 49-70.

D'Amours, D. (1993). The distribution of cod (Gadus morhua) in relation to temperature and oxygen levels in the Gulf of St. Lawrence. Oceanography 2, 2429.

Diaz, R. J. and Rosenberg, R. (1995). Marine benthic hypoxia: a review of its ecological effects and the behavioural responses of benthic macrofauna. Oceangr Mar. Biol. 33, 245-303.

Driedzic, W. R., Gesser, H. and Johansen, K. (1985). Effects of hypoxic adaptation on myocardial performance and metabolism of Zoarces viviparus. Can. J. Zool. 63 , 821-823.

Dutil, J. D., Sylvestre, E. L., Gamache, L., Larocque, R. and Guderley, H. (2007) Burst and coast use, swimming performance and metabolism of Atlantic cod Gadus morhua in sub-lethal hypoxic conditions. J. Fish. Biol. 71, 363-375

Evans, D. O. (2007). Effects of hypoxia on scope-for-activity and power capacity of lake trout (Salvelinus namaycush). Can. J. Fish. Aquat. Sci. 64, 345-361.

Farrell, A. P. (2002). Cardiorespiratory performance in salmonids during exercise at high temperature: Insights into cardiovascular design limitations in fishes. Comp. Biochem. Physiol. 132A, 797-810.

Faust, H. A., Gamperl, A. K. and Rodnick, K. J. (2004). All trout are not created equal: intra-specific varaition in cardiac hypoxia tolerance. J. Exp. Biol. 207, 1005 1015.

Fitzgibbon, Q. P., Strawbridge, A. and Seymour, R. S. (2007). Metabolic scope, swimming performance and the effects of hypoxia in the mulloway, Argyrosomus japonicus (Pisces: Sciaenidae). Aquaculture 270, 358-368.

Fritsche, R. and Nilsson, S. (1989). Cardiovascular responses to hypoxia in the Atlantic cod, Gadus morhua. Exp. Biol. 48, 153-160.

Fry, F. E. J. (1971). The effects of environmental factors on the physiology of fish. In Fish Physiology, Vol. 6 (ed. W. S. Hoar and D. J. Randall). New York: Academic Press.

Gamperl, A. K., Pinder, A. W., Grant, R. R. and Boutilier, R. G. (1994). Influence of hypoxia and adrenaline administration on coronary blood flow and cardiac performance in seawater rainbow trout (Oncorhynchus mykiss). J. Exp. Biol. 193, 209-232.

Gamperl, A. K., Faust, H. A., Dougher, B. and Rodnick, K. J. (2004). Hypoxia tolerance and preconditioning are not additive in the trout (Oncorhynchus mykiss) heart. J. Exp. Biol. 207, 2497-2505

Gamperl, A. K., Swafford, B. L. and Rodnick, K. J. (2007). The impact of elevated water temperature and zatebradine-induced bradycardia on cardiovascular function in male and female rainbow trout (Oncorhynchus mykiss). Integr. Comp. Biol. 47 (S1), e182.

Gamperl, A. K., Busby, C. D., Hori, T. S. F., Afonso, L. O. B. and Hall, J. R. (2009). Haemoglobin genotype has minimal influence on the physiological response of Atlantic cod (Gadus morhua) to environmental challenges. Physiol. Biochem. Zool. 82, 483-494.

Gerlach, S. A. (1988). The Baltic environment. Proceedings of the $10^{\text {th }}$ symposium of the Baltic marine biologists. Sonderheft Kieler Meeresforschungen. 6, 1-462.

Gilbert, D., Sundby, B., Gobeil, C., Mucci, A. and Tremblay, G. H. (2005). A seventy-two year record of diminishing deep water oxygen in the St. Lawrence estuary: The northwest Atlantic connection. Limnol. Oceanogr. 50, 1654-1666.

Gollock, M. J., Currie, S., Petersen, L. H. and Gamperl, A. K. (2006). Cardiovascular and haematological responses of Atlantic cod (Gadus morhua) to acute temperature increase. J. Exp. Biol. 209, 2961-2970.

Greaney, G. S., Allen, R. P., Cashon, R. E., Smith, G. and Powers, D. A. (1980). Time course of changes in enzyme activities and blood respiratory properties of killifish during long-term acclimation to hypoxia. Physiol. Zool. 53, 136-144.

Hanson, L. M., Obradovich, S., Mouniargi, J. and Farrell, A. P. (2006). The role of adrenergic stimulation in maintaining maximum cardiac performance in rainbow trout (Oncorhynchus mykiss) during hypoxia, hyperkalemia and acidosis at $10^{\circ} \mathrm{C}$. J. Exp. Biol. 209, 2442-2445

Heidinger, R. C. (1975). Life history and biology of largemouth bass. In Black Bass Biology and Management (ed. R. H. Stroud and H. Clepper), pp. 11-20. Washington DC: Sport Fishing Institute.

Hoback, W. W. and Barnhart, M. C. (1996). Lethal limits and sublethal effects of hypoxia on the amphipod Gammarus pseudolimnaeus. J. Nth. Amer. Benth. Soc. 15, 117-126.

Hutchings, J. A. and Reynolds, J. D. (2004). Marine fish population collapses: consequences for recovery and extinction risk. Bioscience 54, 297-309.

Jain, K. E. and Farrell, A. P. (2003). Influence of seasonal temperature on the repeat swimming performance of rainbow trout Oncorhynchus mykiss. J. Exp. Biol. 206, 3569-3579.
Jain, K. E., Birtwell, I. K. and Farrell, A. P. (1998). Repeat swimming performance of mature sockeye salmon following a brief recovery period: a sensitive measure of fish health and water quality. Can. J. Zool. 76, 1488-1496.

Kiceniuk, J. W. and Colbourne, E. (1997). Relating oxygen levels in the Newfoundland offshore waters to the physiology of Atlantic cod (Gadus morhua). Can. J. Fish. Aqua. Sci. 54, 81-87.

Killen, S. S., Costa, I., Brown, J. A. and Gamperl, A. K. (2007). Little left in the tank: metabolic scaling in marine teleosts and its implications for aerobic scope. Proc. Royal. Soc. B Biol. Sci. 274, 431-438.

Kutty, M. N. (1968). Influence of ambient oxygen on the swimming performance of goldfish and rainbow trout. Can. J. Zool. 46, 647-653.

Lamarche, M. C., Chabot, D. and Guderley, H. (2009). Effects of acute and chronic hypoxia on metabolic capacity of Atlantic cod (Gadus morhua) from the Gulf of St Lawrence. Comp. Biochem. Physiol. 153A, S142-S142.

Lapointe, D., Guderley, H. and Dutil, J. D. (2006). Changes in the condition factor have an impact on metabolic rate and swimming performance relationships in Atlantic cod (Gadus morhua L.). Physiol. Biochem. Zool. 79, 109-119.

Lee, C. G., Farrell, A. P., Lotto, A., Hinch, S. G. and Healy, M. C. (2003). Excess post-exercise oxygen consumption in adult sockeye (Oncorhynchus nerka) and coho (O. kisutch) salmon following critical speed swimming. J. Exp. Biol. 206, 32533260 .

Lennard, R. and Huddart, H. (1992). The effects of hypoxic stress on the fine structure of the flounder heart (Platichthys flesus). Comp. Biochem. Physiol. 101A, 723-732.

Lomholt, J. P. and Johansen, K. (1979). Hypoxia acclimation in carp-how it affects $\mathrm{O}_{2}$ uptake, ventilation and $\mathrm{O}_{2}$ extraction from water. Physiol. Zool. 5, 3849

MacFarlane, W. J. and MacDonald, D. G. (2002). Relating intramuscular fuel use to endurance in juvenile rainbow trout. Physiol. Biochem. Zool. 75, 250-259.

Marques, I. J., Leito, J. T. D., Spaink, H. P., Testerink, J., Jaspers, R. T., Witte, F., van den Berg, S. and Bagowski, C. P. (2008). Transcriptome analysis of the response to chronic constant hypoxia in zebrafish hearts. J. Comp. Physiol. B 178, 77-92.

Monpetit, C. J. and Perry, S. F. (1998). The effects of chronic hypoxia on the acute adrenergic stress response in the rainbow trout (Oncorhynchus mykiss). Physiol. Zool. 71, 377-386.

Myers, R. A., Hutchings, J. A. and Barrowman, N. J. (1996). Hypotheses for the decline of cod in the North Atlantic. Mar. Ecol. Prog. Ser. 138, 293-308.

Nelson, J. A. (1989). Critical swimming speeds of yellow perch Perca flavescens: comparison of populations from a naturally acidic lake and a circumneutral lake in acid and neutral water. J. Exp. Biol. 145, 239-254.

Neuenfeldt, S. (2002). The influence of oxygen saturation on the distributional overlap of predator (cod, Gadus morhua) and prey (herring, Clupea harengus) in the Bornholm Basin of the Baltic Sea. Fish. Ocean. 11, 11-17.

Paajanen, V. and Vornanen, M. (2003). Effect of hypoxia in inward rectifier $\mathrm{K}^{+}$ current $\left(\mathrm{I}_{\mathrm{KI}}\right)$ in ventricular myocytes of crucian carp (Carassius carassius) heart. $J$. Membr. Biol. 194, 119-127.

Peake, S. J. and Farrell, A. P. (2006). Fatigue is a behavioural response in respirometer confined smallmouth bass. J. Fish. Biol. 68, 1742-1755.

Petersen, L. H. and Gamperl, A. K. (2010). In situ cardiac function in Atlantic cod (Gadus morhua): effects of acute and chronic hypoxia. J. Exp. Biol. 213, 820830.

Pichavant, K., Person-Le Ruyet, J., Le Bayon, N., Sèvère, A., Le Roux, A., Quèmèner, L., Maxime, V., Nonotte, G. and Bœuf, G. (2000). Effect of hypoxia on growth and metabolism of juvenile turbot. Aquaculture 188, 103-114.

Pichavant, K., Person-Le-Ruyet, J., Le Bayon, N., Sèvère, A., Le Roux, A. and Bœuf, G. (2001). Comparative effects of long-term hypoxia on growth, feeding, and oxygen consumption in juvenile turbot and European sea bass. J. Fish. Biol. 59, 875-883.

Pichavant, K., Maxime, V., Soulier, P., Boeuf, G. and Nonnotte, G. (2003). A comparative study of blood oxygen transport in turbot and sea bass: effect of chronic hypoxia. J. Fish. Biol. 62, 928-937.

Pihl, L., Baden, S. P. and Diaz, R. J. (1991). Effects of periodic hypoxia on distribution of demersal fish and crustaceans. Mar. Biol. 108, 349-360.

Pihl, L., Baden, S. P., Diaz, R. J. and Schaffer, L. C. (1992). Hypoxia-induced structural changes in the diet of bottom-feeding fish and crustacea. Mar. Biol. 112 349-361.

Plante, S., Chabot, D. and Dutil, J. D. (1998). Hypoxia tolerance in Atlantic cod. J. Fish. Biol. 53, 1342-1356.

Post, J. R. and Lee, J. A. (1996). Metabolic ontogeny of teleost fishes. Can. J. Fish. Aquat. Sci. 53, 910-923.

Rosenberg, R., Hellman, B. and Johansson, B. (1991). Hypoxic tolerance of marine benthic fauna. Mar. Eco. Prog. Ser. 79, 127-131.

Sandblom, E. and Axelsson, M. (2005). Effects of hypoxia on the venous circulation in rainbow trout (Oncorhynchus mykiss). Comp. Biochem. Physiol. 140A, 233-239.

Sandblom, E. and Axelsson, M. (2006). Adrenergic control of venous capacitance during moderate hypoxia in the rainbow trout (Oncorhynchus mykiss): role of neural and circulating catecholamines. Am. J. Physiol. Regul. Integr. Comp. Physiol. 291, R711-R718.

Saunders, R. L. (1963). Respiration of Atlantic cod. J. Fish. Res. Bd. Can. 20, 373386

Schurmann, H. and Steffensen, J. F. (1997). Effects of temperature, hypoxia and activity on the metabolism of juvenile cod. J. Fish. Biol. 50, 1166-1180.

Steffensen, J. F., Schurmann, H. and Bushnell, P. G. (1994). Oxygenconsumption in four species of teleosts from Greenland - no evidence of metabolic cold adaptation. Polar Biol. 14, 49-54

Steinhausen, M. F., Sandblom, E., Eliason, E. J., Verhille, C. and Farrell, A. P. (2008). The effect of acute temperature increases on the cardiorespiratory 
performance of resting and swimming sockeye salmon (Oncorhynchus nerka). J. Exp. Biol. 211, 3915-3926.

Svedäng, H. and Bardon, G. (2003). Spatial and temporal aspects of the decline in cod (Gadus morhua L.) abundance in the Kattegat and eastern Skagerrak. ICES J. Mar. Sci. 60, 32-37.

Taylor, E. B. and McPhail, J. D. (1985). Variation in burst and prolonged swimming performance among British Columbia populations of coho salmon, Oncorhynchus kisutch. Can. J. Fish. Aquat. Sci. 42, 2029-2033.

Taylor, J. C. and Miller, J. M. (2001). Physiological performance of juvenile southern flounder, Paralichthys lethostigma (Joran and Gilbert, 1884), in chronic and episodic hypoxia. J. Exp. Mar. Biol. Ecol. 258, 195-214.

Timmerman, C. M. and Chapman, L. J. (2004). Hypoxia and interdemic variation in Poecilia latipinna. J. Fish. Biol. 65, 635-650.

UN Global Environment Outlook Year Book (2003). United Nations Environment Programme. ISBN: 9280724150.

Webber, D. M., Boutilier, R. G. and Kerr, S. R. (1998). Cardiac output as a predictor of metabolic rate in cod Gadus morhua. J. Exp. Biol. 201, 2779-2789.
Weeks, S. J., Bronwen, C. and Bakun, A. (2002). Satellite imaging: Massive emissions of toxic gas in the Atlantic. Nature 415, 493-494.

Wood, C. M. and Shelton, G. (1980). The reflex control of the heart rate and cardiac output in the rainbow trout: interactive influences of hypoxia, haemorrhage and systemic vasomotor tone. J. Exp. Biol. 87, 271-284.

Wu, R. S. S. (1999). Eutrophication, trace organics and water-borne pathogens and compounds: Environmental risks and challenges. Mar. Poll. Bull. 39, 11-22.

Wu, R. S. S. (2002). Hypoxia: From molecular responses to ecosystem responses. Mar. Poll. Bull. 45, 35-45.

Wu, R. S. S., Lam, P. K. S. and Wan, K. L. (2002). Tolerance to, and avoidance of hypoxia by the penaeid shrimp (Metapenaeus ensis). Environ. Poll. 118, 351-355.

Wu, R. S. S., Zhou, B. S., Randall, D. J., Woo, N. Y. S. and Lam, P. K. S. (2003) Aquatic hypoxia is an endocrine disruptor and impairs fish reproduction. Environ. Sci. Technol. 37, 1137-1141.

Zhou, B. S., Wu, R. S. S., Randall, D. J. and Lam, P. K. S. (2001). Bioenergetics and RNA/DNA ratios in the common carp (Cyprinus carpio) under hypoxia. J. Comp. Physiol. B 171, 49-57. 